\title{
Radiological and health hazards resulting from radioactivity and elemental composition of some soil samples
}

\author{
Abdu Hamoud AL-KHAWLANY, ${ }^{1, a}$, A. R. KHAN ${ }^{2}$, J. M. PATHAN ${ }^{3}$ \\ ${ }^{1}$ Department of Physics, Dr. Babasaheb Ambedkar University, Aurangabad, Maharashtra, India-431001. \& Department \\ of Physics, Faculty of Education \& Languages, Amran University, Amran, Yemen. \\ ${ }^{2}$ Department of Computer Science, Maulana Azad College, Dr. Babasaheb Ambedkar University, Aurangabad, Maharashtra, \\ India-431001. \\ ${ }^{3}$ Department of Physics, Maulana Azad College, Dr.Babasaheb Ambedkar University, Aurangabad, Maharashtra, India- \\ 431001. \\ ${ }^{a}$ E-mail address: abdu.alkhawlany@gmail.com
}

(received 23 November 2019; revised 1 February and 20 February 2020; accepted 4 May 2020)

\begin{abstract}
Inspection of the radioactivity level in the soil is very important for human health and environmental protection. This study aims at evaluating the radiological hazards and pollution risks related to natural radionuclides and elements in the selected soil samples. Ten samples of soil were collected from different sites of Aurangabad-India and the level of radioactivity was measured using gamma-ray spectrometry with $\mathrm{NaI}(\mathrm{Tl})$ detector. Furthermore, the Physico-chemical properties such as $\mathrm{pH}$, organic matter, electrical conductivity, moisture, soil texture, etc., and elemental composition of soils have been decided on using various standard techniques. The mean concentrations of ${ }^{226} \mathrm{Ra},{ }^{232} \mathrm{Th}$, and ${ }^{40} \mathrm{~K}$ were 8.178, 17.408, and $96.496 \mathrm{~Bq} / \mathrm{kg}$, respectively, which are lower than the global average values of 35, 30, and 400 $\mathrm{Bq} / \mathrm{kg}$, respectively (UNSCEAR, 2000). The radiological hazard indices such as radium equivalent, absorbed dose, annual effective dose, internal index, external index, gamma index, excess lifetime cancer risk, etc., were calculated to assess the radiation hazards and compared with internationally recommended values which found to be lower than the permissibility limits.

The Pearson correlation was applied to determine the existing relationship between radionuclides and radiological health hazard parameters, as well as with the physicochemical properties of the soil samples. The major and trace elements presented in soils were measured and their mean concentration was ranked in the formed order $(\mathrm{Mg}>\mathrm{Na}>\mathrm{Ca}>\mathrm{K}>\mathrm{N}>\mathrm{Mn}>\mathrm{Fe}>\mathrm{P}>\mathrm{Zn}>\mathrm{Cu})$. The pollution risk parameters (Geo-accumulation index, contamination factor, degree of contamination, pollution load index, and potential ecological risk index) related to the elements in the samples were assessed and results shown that the soils under study are unpolluted with the measured elements. Generally, the radioactivity levels and pollution risks indices in the soils of the study area are within the permissible safety limits and do not cause any significant health threat to humans. Thus, the presented data provide a general background of the detectable radionuclides for the study area and can be helpful in the future as a reference for more extensive studies in the same field.
\end{abstract}

Key words: health hazards; radionuclides; gamma spectrometry; physico-chemical properties; absorbed dose.

\section{Introduction}

All the materials on the earth contain different amounts of natural radionuclides. Humans are exposed to natural radioactivity because of the primordial radionuclides such as ${ }^{40} \mathrm{~K},{ }^{232} \mathrm{Th}$, and ${ }^{238} \mathrm{U}$ series that exist in varying amounts in soil, building materials, water, rocks, and the atmosphere. The exposure to the gamma-ray from these radionuclides on the body and the irradiation of lung tissue from inhalation of radon and its daughters cause the radiological effects. Evaluating of gamma-ray dose from natural sources is vital as natural radiation is considered the largest contributor to the external dose of the population [1,2]. Knowing the distribution of natural radioactivity in soil, rock, building materials, and food plays a vital role in protecting the environment, geoscientific research and guiding for the use and management of these materials. Most of the countries within the world implement surveys to evaluate radioactivity levels to collect data regarding possible radiological hazards and to take necessary protection. Radionuclides such as uranium exhibit a serious threat, even at small concentrations due to high chemical toxicity and

(C) 2020 Abdu Hamoud Al-khawlany, A. R. Khan, J. M. Pathan. This is an open access article licensed under the Creative Commons Attribution-NonCommercialNoDerivs License (http://creativecommons.org/licenses/by-nc-nd/3.0/). 
radioactivity altogether. Increasing demands have caused higher anthropogenic environmental contamination of such toxic metals along with the natural release. Radionuclides are produced artificially by different industrial activities which include "nuclear reactors, mining, nuclear power plant accidents, laboratory investigations, particle accelerators, power weapon tests, radionuclide generators, nuclear energy activities, etc." [3-5]. These contaminants get deposited on the ground based on their weight, and later heavy rains can bring the radioactive particle to the ground [6,7]. Intensive surveys and investigations on natural radiations have received considerable attention in many countries (UNSCEAR, 2000) [1]. High radiation levels have been reported in parts of India, Italy, France, and Brazil. In Egypt, along the Nile delta studies show that clay soils have higher radiation activity than sandy soils. In Sri Lanka, a similar study on clay bricks shows low levels of hazards [8]. This subject has not been studied by researchers in Aurangabad, Maharashtra-India, and this research work is to be the first in this area. This study is beneficial to the authority and the people of Aurangabad-India as it provides information and data for the evaluation of the radiation exposure levels associated with soils use in the district. The main objective of this study is to assess health hazards to humans from the radioactivity and elements in the soil samples from the outskirts of Aurangabad, India, as this is a historic region with a documented history and having monuments of world heritage for tens of centuries. Physicochemical parameters play a major role in the distribution and behavior of radionuclides in the soil. Therefore, the study of Physico-chemical parameters of the surface soil constitutes one of the most important aspects of the present study. It is a wellbased incontrovertible fact that any change in the radionuclide content of varied components of the ecosystem depends on the interactions of various number of factors including the radionuclides itself and the location-specific characteristics, like soil type (clay, sand, silt) and its physicochemical properties, climate changes, etc. The chemical composition of the soil, particularly its metal content, is environmentally important because depending on their concentrations, levels of toxic elements can reduce soil fertility, can increase input to the food chain, which leads to accumulating toxic metals in foodstuffs, and ultimately can endanger human health. In the current work, the collected soil samples from Aurangabad, India, were analyzed using a passively shielded $\mathrm{NaI}(\mathrm{Tl})$ detector to determine the levels of activity concentrations from ${ }^{226} \mathrm{Ra},{ }^{232} \mathrm{Th}$, and ${ }^{40} \mathrm{~K}$. Moreover, Physico-chemical properties and elemental composition of the soil samples have been determined using different standard analytical techniques.

\section{Materials and Methods}

\section{Sample collection and preparation}

The soil samples were collected from ten sites of AurangabadMaharashtra, India (Figure 1) as this is a historic region with a documented history and having monuments of world heritage for tens of centuries. The study area located between latitudes $19.926436-20.052340^{\circ} \mathrm{N}$ and longitudes 75.329620$75.188994^{\circ} \mathrm{E}$. Soil sampling was conducted during the period of July-September 2017 which corresponds to the raining season in this region. The samples were collected by using the clean plastic scoop and stored in polyethylene bags. Samples were collected with the only constraint that no sampling site should be taken close to a field boundary, a road, a tree or other obstruction. About $2 \mathrm{~kg}$ of the samples were collected from each location. Surface soils were taken from different places within the cleared area from the ground surface up to $5 \mathrm{~cm}$ and mixed together thoroughly in order to obtain a representative sample of that area. Samples that are collected from various locations were brought to the laboratory. Organic materials, roots, vegetation, pebbles, etc., if present were removed and the samples were initially sun-dried by spreading them in a tray. After removing the stones, the samples were dried in the furnace at $110^{\circ} \mathrm{C}$ for 24 hours to remove moisture and ground it into a powder of suitable size. Then samples were sieved through 100 mesh which is the optimum size enriched in heavy mineral. These samples were filled in plastic containers with $7 \mathrm{~cm}$ diameter and $10 \mathrm{~cm}$ in height. Sample containers were filled with $500 \mathrm{gm}$ of samples for uniformity depending upon the density of the sample. These sample containers were stored for a period of 1 month before gamma spectrometric analysis so as to allow the establishment of a secular equilibrium between ${ }^{226} \mathrm{Ra},{ }^{232} \mathrm{Th}$, and their respective progeny products.

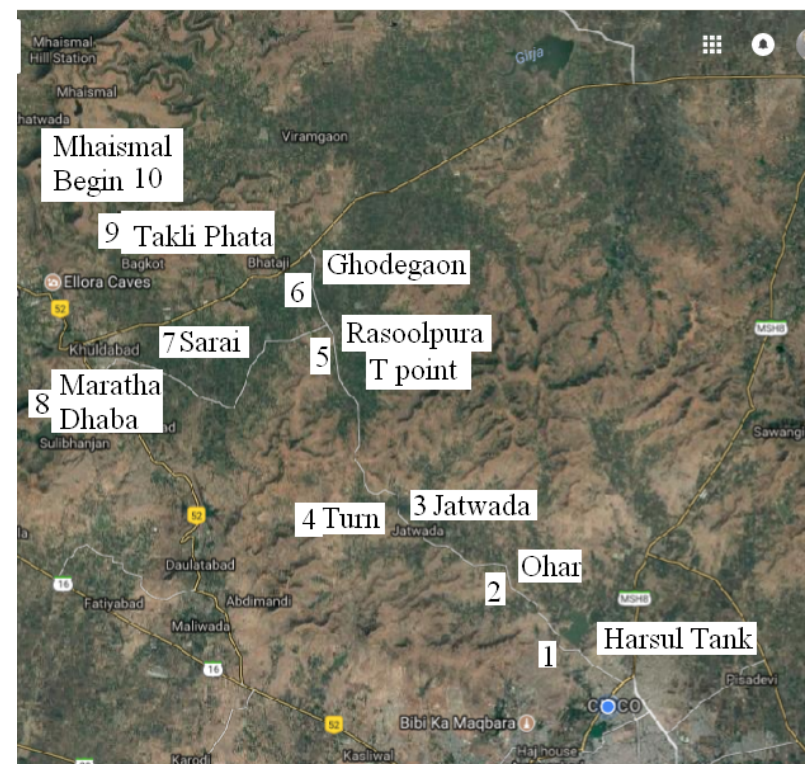

Figure 1. Locations map around Aurangabad-India, wherefrom samples were collected 


\section{Radionuclides measurements}

The analysis of natural radionuclide concentrations was performed by utilizing gamma-ray spectrometry with $\mathrm{NaI}$ (Tl) detector coupled with a multichannel analyzer $8 \mathrm{~K}$ channel, with resolution full-width maximum half (FWMH) at $662 \mathrm{keV}$ ${ }^{137} \mathrm{Cs}$ about $40 \mathrm{keV}$ and about $60 \mathrm{keV}$ for the photopeak of ${ }^{60} \mathrm{Co}$ at $1330 \mathrm{keV}$, relative efficiency at $662 \mathrm{keV}{ }^{137} \mathrm{Cs}$ is $7 \%$ and relative efficiency at $1330 \mathrm{keV}{ }^{60} \mathrm{Co}$ is $8 \%$. The detector is shielded during a chamber of two layers starting with stainless steel. This shield work for reducing different background radioactivity. The spectrometer was calibrated for energy and efficiency over the photon energy range 123 to $1330 \mathrm{keV}$ using IAEA standard reference radioactive sources ${ }^{57} \mathrm{Co},{ }^{133} \mathrm{Ba},{ }^{137} \mathrm{Cs}$, ${ }^{54} \mathrm{Mn},{ }^{22} \mathrm{Na}$, and ${ }^{60} \mathrm{Co}$. It has been procured from the Bhabha Atomic Research Centre (BARC), Mumbai-India, which were used for calibrated energy and efficiency. The channel numbers of the photopeaks corresponding to the various gamma energies were recorded after $1200 \mathrm{~s}$ and therefore the obtained energy-channel linear relationship is shown in Figure 2. The standard source was put in the same geometry as that used for measured samples. For calibration of a spectrometer, the standard source is put above the detector, and therefore the measurement started. The calibration source was counted for a long time to obtain clear defined photo peaks. The background spectrum was recorded immediately before the sample counting to obtain the net count rate. Each sample was placed in plastic containers of the same size as that of the standard sources. The obtained spectrum was analyzed with the computer software program PHAST-MCS or manually with the utilization of a spreadsheet (Microsoft Excel) to calculate the specific activity of radionuclides. The activity concentration of ${ }^{226} \mathrm{Ra}$ in the samples was evaluated from the photopeaks of ${ }^{214} \mathrm{~Pb}(295.22,351.93 \mathrm{keV}),{ }^{214} \mathrm{Bi}(609.31,1120$ $\mathrm{keV})$ and ${ }^{226} \mathrm{Ra}(186.1 \mathrm{keV})$. Similarly, the activity concentration of ${ }^{232} \mathrm{Th}$ was calculated through the photo peaks of ${ }^{228} \mathrm{Ac}(911.2,209.25,338.32 \mathrm{keV})$ and ${ }^{208} \mathrm{Tl}(2614,583.19$, $860.56 \mathrm{keV})$. The activity of ${ }^{40} \mathrm{~K}$ was evaluated from its own photopeak (1461 keV).

The specific activity concentrations of radionuclides are computed using the following equation:

$$
A=\frac{N}{\varepsilon \times \gamma \times t \times m}
$$

where $\mathrm{A}$ is the activity concentrations of radionuclides in the sample in $\mathrm{Bq} / \mathrm{kg}, \mathrm{N}$ is the net count rate $\left(\mathrm{N}=\mathrm{N}_{\text {Peak }}\right.$ $\mathrm{N}_{\text {Background }}$ ), $\varepsilon$ is the detector efficiency of the photopeak used, $\gamma$ is the absolute transition of gamma decay, $t$ is the counting time in seconds, and $\mathrm{m}$ is mass of sample in $\mathrm{kg}$.

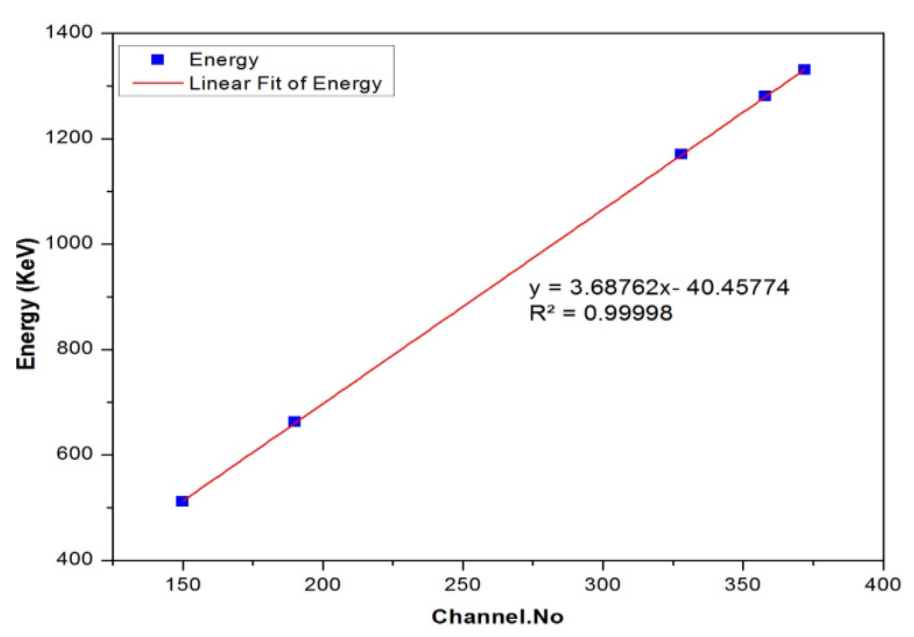

Figure 2. The energy calibration curve for radioactivity measurements in this work

\section{Determination of Physico-chemical properties of the soil}

Physico-chemical parameters such as $\mathrm{pH}$, electrical conductivity, organic matter content, soil texture (sand, silt, and clay), etc., and elemental composition of the soil samples, were determined using different standard procedures $[9,10]$. The soil $\mathrm{pH}$ and electrical conductivity were measured using a $\mathrm{pH}$ meter and $\mathrm{EC}$ meter. The $\mathrm{pH}$ was measured during a 1:2.5 soil-water ratio. The $\mathrm{pH}$ was measured by dipping the $\mathrm{pH}$ meter into the solution until a steady value of $\mathrm{pH}$ was gained. The instrument measuring of $\mathrm{pH}$ was calibrated using the

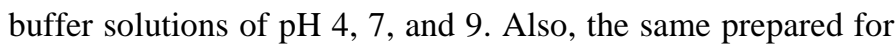
$\mathrm{pH}$ measurement was used for measuring the conductivity in the soil samples. The electrical conductivity of the soil sample was determined by dipping the electrode of the conductivity cell in the soil-water suspension. The EC is measured in milliSiemens per $\mathrm{cm}(\mathrm{mS} / \mathrm{cm})$. The organic carbon method was employed in the measurement of organic matter percentage in the soil samples [11]. The particle size distribution (sand, silt, and clay) was determined in the range of less than $2 \mathrm{~mm}$ fraction by hand feel method. A small amount of soil sample was taken in hand and enough water added to make a ball. This ball was moved between thumb and forefinger to determine the feel characteristics of sand, silt, and clay. The feel characteristics for sand, silt, and clay were gritty, smooth and sticky respectively. The soil ball was pushed between thumb and forefinger to make a ribbon. The longer the ribbon, the more is the clay content in the soil. The ruler was used to measure the length of the ribbon, and the data were recorded. The size fractions were defined as clay $(<0.002 \mathrm{~mm})$, silt ( 0.002 to $0.02 \mathrm{~mm})$, fine sand $(0.02$ to $0.2 \mathrm{~mm})$, and coarse sand $(0.2$ to $2.0 \mathrm{~mm})$. 
Soil texture class was identifying by texture triangle as shown in Figure 3 which presents 12 basic soil textural classes. For example, for a soil to be classified as sand, it should present $85 \%$ or more of sand and the silt plus clay not exceeding $15 \%$. A sand clay loam has from $20 \%$ to $35 \%$ of clay, $45 \%$ of sand or more, and less than $28 \%$ of silt. Clay soil is characterized by more than $40 \%$ of clay and less than $45 \%$ of sand and $40 \%$ of silt. The elemental composition of the dry soil samples was analyzed by an X-ray fluorescence spectrometer (XRF, SPECTRO XEPOS, AMETEK). Energy-dispersive X-ray fluorescence (EDXRF) is a nuclear analytical technique commonly used in environmental research. The principle work of the X-ray fluorescence technique is based on that when the individual atoms excited by an external energy source, the $\mathrm{X}$ ray photons of a characteristic energy or wavelength will be emitted. Therefore, the elements present in the sample can be determined and quantified by counting the number of photons of each energy emitted from a sample. It requires at least $5 \mathrm{gm}$ of dry fine powder sample. The instrument (SPECTRO XEPOS) was controlled by a menu based X-LAB pro software computer. This instrument characteristics included; 50 watts end-window X-ray tube, up to eight polarization, and secondary targets, automatic sample changer, SSD detection system. Standards used in the XRF peak calibration are as follows: Glass tablets FLX-SP1, Voltage/kV: 38.0, Current/ $\mu \mathrm{A}$ : 15.0 for MCA peak calibration and FLX-SP2 along with the global calibration.

\section{Calculation of radiological hazard parameters}

\section{Radium equivalent activity (Raeq)}

Radiation exposure is often defined in terms of the many radiological parameters. It is known that radium equivalent activity is one of the extensively used hazard indices. It is defined based on the assumption that $10 \mathrm{~Bq} / \mathrm{kg}$ of ${ }^{226} \mathrm{Ra}, 7$ $\mathrm{Bq} / \mathrm{kg}$ of ${ }^{232} \mathrm{Th}$ and $130 \mathrm{~Bq} / \mathrm{kg}$ of ${ }^{40} \mathrm{~K}$ produce the same gamma dose rate. It was calculated through the following equation [12]:

Raeq $=A_{\mathrm{Ra}}+1.43 A_{\mathrm{Th}}+0.077 A_{\mathrm{K}}$ Eq. 2 where $A_{R a}, A_{T h}$, and $A_{K}$ are the concentrations of ${ }^{226} \mathrm{Ra},{ }^{232} \mathrm{Th}$, and ${ }^{40} \mathrm{~K}$ in $\mathrm{Bq} / \mathrm{kg}$, respectively.

\section{Absorbed gamma dose rate $\left(D_{R}\right)$}

The absorbed dose in air expresses the received dose in the open air from the radiation released from natural radionuclides in the environmental materials. This parameter is a very important quantity for assessment when considering radiation hazard to a biosystem. The absorbed dose rate due to gamma radiations for the uniform distribution of naturally occurring radionuclides was computed using the following relation [13].

$\mathrm{D}_{\mathrm{ab}}=0.462 A_{\mathrm{Ra}}+0.604 A_{\mathrm{Th}}+0.0417 \mathrm{~A}_{\mathrm{K}}$

Eq.3

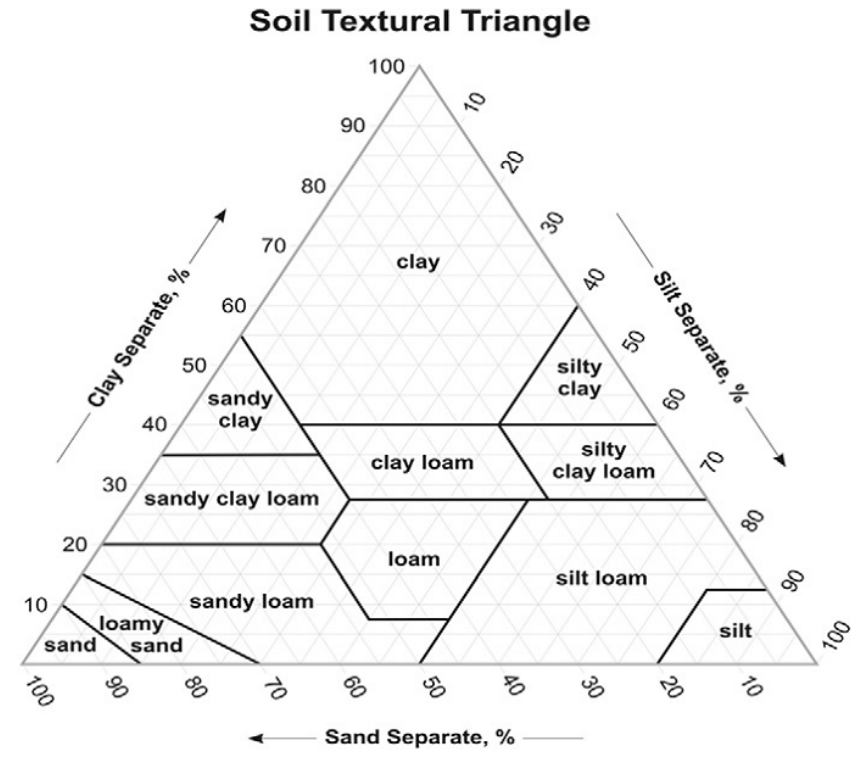

Figure 3. Soil textural triangle which is used to identify the soil texture class

\section{Annual effective dose equivalent (AEDE)}

The absorbed dose rate was used to calculate the annual effective dose equivalent received by a member by applying the dose conversion factor of $0.7 \mathrm{~Sv} / \mathrm{Gy}$ where the occupancy factor for outdoor was 0.2 [13]. It is calculated using the following equation:

$\mathrm{AEDE}=\mathrm{D}_{\mathrm{R}} \times 8760 \times 0.7 \times 0.2 \times 10^{-6} \mathrm{mSv} / \mathrm{y}$

Eq.4

External and internal hazard indices $\left(H_{e x} \& H_{i n}\right)$

The external hazard index $\left(\mathrm{H}_{\mathrm{ex}}\right)$ represents the external radiation exposure associated with gamma emission from radioisotopes in the sample. The value of $\mathrm{H}_{\mathrm{ex}}$ must not exceed the maximum acceptable value than unity to maintain considerable danger. This index can be evaluated using the following equation [14]:

$\mathrm{H}_{\mathrm{ex}}=\left(\mathrm{A}_{\mathrm{Ra}} / 370\right)+\left(\mathrm{A}_{\mathrm{Th}} / 259\right)+\left(\mathrm{A}_{\mathrm{K}} / 4810\right) \leq 1$

Eq. 5

The internal hazard index $\left(\mathrm{H}_{\mathrm{in}}\right)$ is used to control the internal exposure to ${ }^{222} \mathrm{Rn}$ and its radioactive progeny [15]. The internal exposure to radon and its daughter products is quantified by the $\mathrm{H}_{\mathrm{in}}$ which is given by the following equation:

$\mathrm{H}_{\mathrm{in}}=\left(\mathrm{A}_{\mathrm{Ra}} / 185\right)+\left(\mathrm{A}_{\mathrm{Th}} / 259\right)+\left(\mathrm{A}_{\mathrm{K}} / 4810\right) \leq 1$

Eq. 6

where $A_{R a}, A_{T h}$, and $A_{K}$ are the activity concentrations of ${ }^{226} \mathrm{Ra}$, ${ }^{232} \mathrm{Th}$, and ${ }^{40} \mathrm{~K}$, respectively.

\section{Gamma representative level index $\left(I_{\gamma}\right)$}

Gamma index $\left(\mathrm{I}_{\gamma}\right)$ is employed to work out the extent of gamma-ray hazards related to the natural radionuclides in the samples. It is calculated using the following equation [16]:

$\mathrm{I}_{\gamma}=\left(\mathrm{A}_{\mathrm{Ra}} / 150\right)+\left(\mathrm{A}_{\mathrm{Th}} / 100\right)+\left(\mathrm{A}_{\mathrm{K}} / 1500\right) \leq 1$

Eq.7 


\section{Annual gonadal dose equivalent (AGDE)}

According to UNSCEAR, the gonads, active bone marrow, and bone surface cells are considered the organs of interest. The annual gonadal dose equivalent (AGDE) in $\mathrm{mSv} / \mathrm{y}$ due to the activity concentrations of ${ }^{226} \mathrm{Ra},{ }^{232} \mathrm{Th}$, and ${ }^{40} \mathrm{~K}$ was calculated using the following formula [17]:

$\operatorname{AGDE}(\mathrm{mSv} / \mathrm{y})=3.09 \mathrm{~A}_{\mathrm{Ra}}+4.18 \mathrm{~A}_{\mathrm{Th}}+0.31 \mathrm{~A}_{\mathrm{K}}$

Eq. 8

Alpha index $\left(I_{\alpha}\right)$

This index is used to assess the excess alpha radiation due to radon inhalation originating from building materials. In the present work, $(\mathrm{I} \alpha)$ was determined through the following formula [18]:

$I_{\alpha}=\left(\frac{A_{R a}}{200}\right) \leq 1$

where $A_{R a}$ is the activity concentration of ${ }^{226} \mathrm{Ra}$. The recommended maximum concentration of ${ }^{226} \mathrm{Ra}$ is $200 \mathrm{~Bq} / \mathrm{kg}$, which gives $I_{\alpha}=1$.

\section{Excess lifetime cancer risk (ELCR)}

he values of the annual effective dose were used to calculate the excess lifetime cancer risk (ELCR) using the following equation [19]:

$\mathrm{ELCR}=\mathrm{AEDE} \times \mathrm{DL} \times \mathrm{RF}$

where AEDE is the annual effective dose equivalent, DL is the duration of life (70 years), and $\mathrm{RF}\left(\mathrm{Sv}^{-1}\right)$ is a fatal risk factor per Sievert, which is 0.05 as per ICRP-60.

\section{Pollution risk indices}

Geo-accumulation index ( $\left.I_{\text {geo }}\right)$

The geo-accumulation index is a common index used for assessing heavy metal pollution in soils and provides an arrangement for the degree of metal enrichment in comparison to the background. It was calculated using the following formula [20]:

$I_{\text {geo }}=\log _{2}\left[C_{n} / 1.5 \times B_{n}\right]$

where $C_{n}$ is the concentration of measured metal (n), $B_{n}$ is the background concentration of the same metal (n), and 1.5 is a multiplying factor of natural variability.

\section{Contamination factor $(C F)$ and degree of contamination $(C d)$}

The $\mathrm{CF}$ is that the ratio gained by dividing the concentration of each metal in the soil by the baseline or background value. The $\mathrm{Cd}$ of the environment is, therefore, defined as the sum of contamination factors for all elements examined and determined using the following equation [21]:

$\mathrm{C}_{\mathrm{F}}=\mathrm{C}_{\mathrm{n}} / \mathrm{B}_{\mathrm{n}}$, and $\mathrm{Cd}=\sum_{i=1}^{n} C F i$

where $\mathrm{CF}$ contamination factor, $\mathrm{C}_{\mathrm{n}}$ is the measured concentration of metal in the sample, $\mathrm{B}_{\mathrm{n}}$ is the background value for the same metal, and $C_{d}$ is the degree of contamination.

\section{Pollution load index (PLI)}

This index is used to evaluate the extent of metal pollution for each soil sample site. The PLI of the study area is calculated by obtaining the n-root from the n-CFs that were obtained for all the metals. The PLI provides a simple and comparative means for assessing soil quality, where a value of PLI $<1$ indicates no pollution; PLI =1 suggests that only baseline levels of pollutants and PLI > 1 indicates pollution and deterioration of soil quality. This index was developed by Tomlinson [22], and calculated with the following equation:

$P L I=\sqrt[n]{\left(C F_{1} \times C F_{2} \times C F_{3} \times \ldots \times C F_{n}\right)}$

Eq. 13

where $\mathrm{CF}$ is the contamination factor and $\mathrm{n}$ is the number of metals studied in the sample.

Potential ecological risk index (RI)

The potential ecological risk index method was proposed by Hakanson [21], to assess the characteristics and environmental behavior of heavy metal contaminants in soils. RI was presented for assessing the degree of heavy metal pollution in soils, in regard with the toxicity of heavy metals and the response of the environment where (RI) is calculated as the total of all risk factors for heavy metals in the selected sample as given by the following equation:

$\mathrm{E}_{\mathrm{r}}^{\mathrm{i}}=\mathrm{T}_{\mathrm{r}}^{\mathrm{i}} \times \mathrm{CF}^{\mathrm{i}}$, and $R I=\sum_{i=1}^{n} E_{r}^{i}$

Eq. 14

where $\mathrm{E}_{\mathrm{r}}^{\mathrm{i}}$ is the potential ecological risk factor, $\mathrm{CF}$ is the contamination factor, and $\mathrm{T}_{\mathrm{r}}^{\mathrm{i}}$ is the toxic response factor $(\mathrm{Mn}=$ $\mathrm{Zn}=1$, and $\mathrm{Cu}=5$ ).

\section{Results and Discussions}

\section{Activity concentrations of radionuclides in the soil}

The activity concentrations of primordial radionuclides in the soil samples were measured and presented in Table 1. The activity concentration of ${ }^{226} \mathrm{Ra},{ }^{232} \mathrm{Th}$, and ${ }^{40} \mathrm{~K}$ are in the range from 4.169 to $12.862 \mathrm{~Bq} / \mathrm{kg}, 8.658$ to $21.316 \mathrm{~Bq} / \mathrm{kg}$, and 40.088 to $130.871 \mathrm{~Bq} / \mathrm{kg}$, with a mean value of $8.178,17.408$, and $96.496 \mathrm{~Bq} / \mathrm{kg}$, respectively, which are less than that of the global average values of 35,30 , and $400 \mathrm{~Bq} / \mathrm{kg}$, respectively (UNSCEAR, 2000). The activity of ${ }^{232} \mathrm{Th}$ series is to be greater than that of ${ }^{238} \mathrm{U}$ series $\left({ }^{226} \mathrm{Ra}\right)$ in most of the studied soil samples, supportive to the very fact that the presence of thorium is 1.5 times greater than that of uranium in the earth's crust. It had been noted that the activity concentrations of ${ }^{226} \mathrm{Ra}$ and ${ }^{232} \mathrm{Th}$ in the soil samples weren't uniform, which represents the variations within the geological, geochemical and physicochemical characteristics of the soils. It had been also observed that the measured activity of ${ }^{40} \mathrm{~K}$ exceeded the values of both ${ }^{226} \mathrm{Ra}$ and ${ }^{232} \mathrm{Th}$, are both the foremost abundant 
radioisotope present in the environment, and it is also noted that potassium is employed extensively as part of an NPK fertilizer medium in intensive agricultural activities to promote the vigorous growth of crops. The present study indicates that the mean value of ${ }^{226} \mathrm{Ra}<{ }^{232} \mathrm{Th}<{ }^{40} \mathrm{~K}$. Radionuclides ${ }^{226} \mathrm{Ra}$ and ${ }^{232} \mathrm{Th}$ are commonly occurring together in nature. This frequently leads to a relatively constant ${ }^{226} \mathrm{Ra} /{ }^{232} \mathrm{Th}$ ratio in many natural systems. This ratio may change from the original value if the sample was undergoing to physical or chemical interactions which will affect one series more or but the opposite one. The calculated ${ }^{226} \mathrm{Ra} /{ }^{232} \mathrm{Th}, \quad{ }^{232} \mathrm{Th} /{ }^{226} \mathrm{Ra}$, ${ }^{232} \mathrm{Th} /{ }^{40} \mathrm{~K}$, and ${ }^{226} \mathrm{Ra} /{ }^{40} \mathrm{~K}$ ratios are given in Table 1. The activity ratios may be used as an indicator of the relative occurrence of these radionuclides.

\section{Radiological health risk assessment}

The radiological hazard parameters are calculated from the results of the activity concentrations of ${ }^{226} \mathrm{Ra},{ }^{232} \mathrm{Th}$, and ${ }^{40} \mathrm{~K}$ in the soil samples and listed in Table 2. It was found that the radium equivalent activity varying from 29.3789 to 50.6377 $\mathrm{Bq} / \mathrm{kg}$, with the mean value of $40.5023 \mathrm{~Bq} / \mathrm{kg}$. The maximum value of Raeq is $50.6377 \mathrm{~Bq} / \mathrm{kg}$ which does not exceed the recommended value of $370 \mathrm{~Bq} / \mathrm{kg}$ corresponds to a dose limit of $1 \mathrm{mSv}$ for the public population [23, 24]. The absorbed gamma dose rate varies from 13.6399 to $22.8246 \mathrm{nGy} / \mathrm{h}$ with a mean value of $18.3169 \mathrm{nGy} / \mathrm{h}$. This value is lower than the recommended international levels of $59 \mathrm{nGy} / \mathrm{h}$. The value of the annual effective dose ranges from 0.0167 to $0.0270 \mathrm{mSv} / \mathrm{y}$ with a mean value of $0.0224 \mathrm{mSv} / \mathrm{y}$ which is less than the worldwide average value of $0.07 \mathrm{mSv} / \mathrm{y}$. The values of the gamma index were ranged from 0.2139 to 0.3629 . It's observed that each one sample has gamma index $\mathrm{I} \gamma<1$ which suggests gamma dose rate emission from these samples was not exceeding $0.3 \mathrm{mSv} / \mathrm{y}$ [25]. The calculated values of $\mathrm{H}_{\mathrm{ex}}$ were found to vary from 0.0794 to 0.1368 , with a mean value of 0.1094 . These values are much less than the limit value of unity and below the measured values in other countries. The values of $\mathrm{H}_{\text {in }}$ were found to range between 0.0939 and 0.1715 with a mean value of 0.1315 . The obtained values of $\mathrm{H}_{\text {in }}$ are less than unity, as recommended for construction materials. It is observed that the values of the internal hazard index are greater than the external hazard index as shown in Figure 4.

Table 1. The activity concentration of natural radionuclides in $(\mathrm{Bq} / \mathrm{kg})$ in the soil samples

\begin{tabular}{|c|c|c|c|c|c|c|c|c|c|}
\hline Sample ID & Latitude & Longitude & ${ }^{226} \mathbf{R a}$ & ${ }^{232} \mathrm{Th}$ & ${ }^{\overline{40} K}$ & Ra/Th & Th/Ra & Th/K & $\mathbf{R} \mathbf{R a} / \mathbf{K}$ \\
\hline $\mathrm{S} 1$ & 19.926436 & 75.329620 & 9.906 & 20.460 & 60.508 & 0.484 & 2.065 & 0.338 & 0.164 \\
\hline $\mathrm{S} 2$ & 19.946103 & 75.313918 & 12.862 & 20.979 & 100.983 & 0.613 & 1.631 & 0.208 & 0.127 \\
\hline S3 & 19.956592 & 75.285846 & 8.280 & 19.229 & 120.020 & 0.431 & 2.322 & 0.160 & 0.069 \\
\hline $\mathrm{S} 4$ & 19.966837 & 75.273615 & 7.470 & 21.316 & 120.142 & 0.350 & 2.854 & 0.177 & 0.062 \\
\hline S5 & 19.976981 & 75.268358 & 7.425 & 18.898 & 70.668 & 0.393 & 2.545 & 0.267 & 0.105 \\
\hline S6 & 20.009619 & 75.261971 & 5.560 & 19.768 & 40.088 & 0.281 & 3.555 & 0.493 & 0.139 \\
\hline S7 & 20.019780 & 75.223154 & 4.169 & 12.010 & 120.061 & 0.347 & 2.881 & 0.100 & 0.035 \\
\hline S8 & 20.023803 & 75.186384 & 9.992 & 8.658 & 90.986 & 1.154 & 0.866 & 0.095 & 0.110 \\
\hline S9 & 20.048840 & 75.196791 & 8.313 & 14.757 & 110.634 & 0.563 & 1.775 & 0.133 & 0.075 \\
\hline S10 & 20.052340 & 75.188994 & 7.807 & 18.007 & 130.871 & 0.434 & 2.307 & 0.138 & 0.060 \\
\hline Minimum & - & - & 4.169 & 8.658 & 40.088 & 0.281 & 0.866 & 0.095 & 0.035 \\
\hline Maximum & - & - & 12.862 & 21.316 & 130.871 & 1.154 & 3.555 & 0.493 & 0.164 \\
\hline Mean Value & - & - & 8.178 & 17.408 & 96.496 & 0.505 & 2.280 & 0.211 & 0.095 \\
\hline
\end{tabular}

Table 2. Radium equivalent activity, absorbed dose rate, annual effective dose, radiation hazard indices, annual gonadal dose equivalent, and excess lifetime cancer risk for soils.

\begin{tabular}{|c|c|c|c|c|c|c|c|c|c|}
\hline Sample ID & $\begin{array}{c}\mathbf{R a} \mathbf{a}_{\mathbf{e q}} \\
(\mathbf{B q} / \mathbf{k g})\end{array}$ & $\begin{array}{c}D_{\mathrm{R}} \\
(\mathrm{nGy} / \mathrm{h})\end{array}$ & $\begin{array}{c}\text { AEDE } \\
(\mathrm{mSv} / \mathrm{y})\end{array}$ & $\mathbf{H}_{\text {in }}$ & $\mathbf{H}_{\mathrm{ex}}$ & $\mathbf{I}_{\gamma}$ & $\begin{array}{l}\text { AGDE } \\
(\mathrm{mSv} / \mathrm{y})\end{array}$ & $\mathbf{I}_{\alpha}$ & $\mathrm{ELCR} \times 10^{-3}$ \\
\hline $\mathrm{S} 1$ & 43.8229 & 19.4576 & 0.0239 & 0.1451 & 0.1184 & 0.3109 & 0.135 & 0.0495 & 0.837 \\
\hline $\mathrm{S} 2$ & 50.6377 & 22.8246 & 0.0270 & 0.1715 & 0.1368 & 0.3629 & 0.159 & 0.0643 & 0.945 \\
\hline $\mathrm{S} 3$ & 45.0190 & 20.4445 & 0.0251 & 0.1439 & 0.1216 & 0.3275 & 0.143 & 0.0414 & 0.879 \\
\hline $\mathrm{S} 4$ & 47.2028 & 21.3359 & 0.0262 & 0.1477 & 0.1275 & 0.3431 & 0.149 & 0.0374 & 0.917 \\
\hline S5 & 39.8906 & 17.7916 & 0.0218 & 0.1278 & 0.1077 & 0.2856 & 0.124 & 0.0371 & 0.763 \\
\hline S6 & 36.9150 & 16.1803 & 0.0198 & 0.1147 & 0.0997 & 0.2615 & 0.112 & 0.0278 & 0.693 \\
\hline S7 & 30.5880 & 14.1867 & 0.0174 & 0.0939 & 0.0826 & 0.2279 & 0.100 & 0.0208 & 0.609 \\
\hline S8 & 29.3789 & 13.6399 & 0.0167 & 0.1064 & 0.0794 & 0.2139 & 0.095 & 0.0499 & 0.585 \\
\hline S9 & 37.9343 & 17.3673 & 0.0213 & 0.1249 & 0.1025 & 0.2768 & 0.122 & 0.0416 & 0.746 \\
\hline $\mathrm{S} 10$ & 43.6341 & 19.9404 & 0.0245 & 0.1389 & 0.1178 & 0.3194 & 0.140 & 0.0390 & 0.858 \\
\hline Minimum & 29.3789 & 13.6399 & 0.0167 & 0.0939 & 0.0794 & 0.2139 & 0.095 & 0.0208 & 0.585 \\
\hline Maximum & 50.6377 & 22.8246 & 0.0270 & 0.1715 & 0.1368 & 0.3629 & 0.159 & 0.0643 & 0.945 \\
\hline Mean & 40.5023 & 18.3169 & 0.0224 & 0.1315 & 0.1094 & 0.2929 & 0.128 & 0.0409 & 0.7832 \\
\hline Critical value & 370 & 59 & 0.07 & $\leq 1$ & $\leq 1$ & $\leq 1$ & 0.3 & $<1$ & $0.290 \times 10^{-3}$ \\
\hline
\end{tabular}




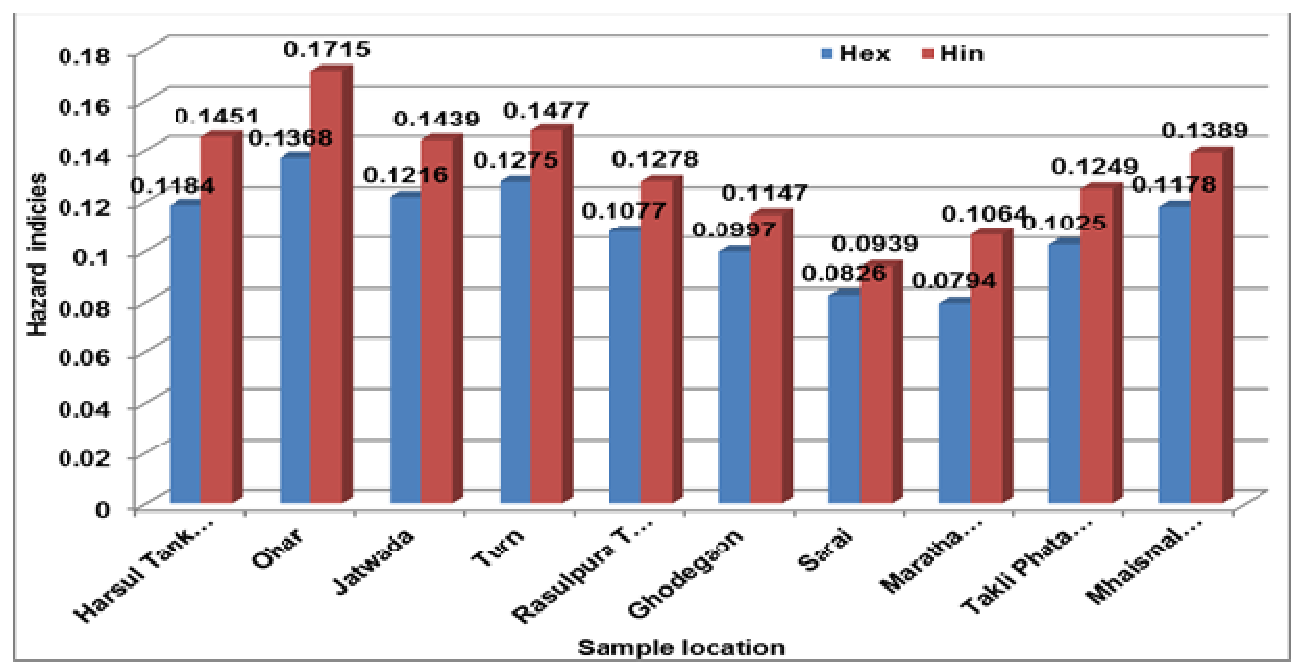

Figure 4. Comparison of external $\left(H_{\mathrm{ex}}\right)$ and internal $\left(\mathrm{H}_{\mathrm{in}}\right)$ radiation hazard indices

Table 3. Physico-chemical properties of the investigated soil samples

\begin{tabular}{|c|c|c|c|c|c|c|c|c|c|}
\hline Sample ID & pH & $\begin{array}{c}\mathrm{EC} \\
(\mathrm{mS} / \mathrm{cm})\end{array}$ & $\begin{array}{l}\text { OM } \\
(\%)\end{array}$ & $\begin{array}{c}\text { Moisture } \\
(\%)\end{array}$ & $\begin{array}{c}\mathrm{CaCO}_{3} \\
(\%)\end{array}$ & $\begin{array}{c}\text { Sand } \\
(\%)\end{array}$ & $\begin{array}{l}\text { Silt } \\
(\%)\end{array}$ & $\begin{array}{c}\text { Clay } \\
(\%)\end{array}$ & Texture class (TC) \\
\hline $\mathrm{S} 1$ & 7.38 & 0.11 & 0.67 & 2.61 & 2.50 & 87.63 & 6.49 & 5.8 & Sandy \\
\hline $\mathrm{S} 2$ & 7.71 & 0.14 & 1.45 & 5.49 & 5.00 & 71.68 & 17.41 & 10.54 & Sandy Loam \\
\hline $\mathrm{S} 3$ & 7.53 & 0.01 & 0.84 & 4.36 & 3.75 & 85.5 & 5.09 & 8.46 & Sandy \\
\hline $\mathrm{S} 4$ & 7.46 & 0.13 & 1.12 & 3.66 & 5.63 & 79.21 & 6.81 & 13.1 & Loamy Sand \\
\hline S5 & 6.61 & 0.08 & 1.28 & 4.82 & 1.25 & 83.63 & 6.36 & 9.96 & Loamy Sand \\
\hline S6 & 6.78 & 0.07 & 0.98 & 3.68 & 1.20 & 85.19 & 5.34 & 9.43 & Sandy \\
\hline S7 & 6.69 & 0.24 & 0.72 & 10.57 & 6.25 & 67.44 & 14.22 & 17.61 & Sandy Loam \\
\hline S8 & 7.17 & 0.14 & 0.47 & 4.53 & 2.63 & 82.9 & 9.14 & 7.16 & Loamy Sand \\
\hline S9 & 7.00 & 0.17 & 1.22 & 4.89 & 1.22 & 80.31 & 10.59 & 9.03 & Loamy Sand \\
\hline $\mathrm{S} 10$ & 6.57 & 0.10 & 0.93 & 3.31 & 2.25 & 88.28 & 10.96 & 0.08 & Sand \\
\hline Range & $6.57-7.71$ & $0.01-0.24$ & $0.47-1.45$ & $2.61-10.57$ & $1.20-6.25$ & $67.44-88.28$ & $5.09-17.41$ & $0.08-17.61$ & - \\
\hline Mean & 7.09 & 0.12 & 0.97 & 4.79 & 3.17 & 81.18 & 9.24 & 9.12 & - \\
\hline
\end{tabular}

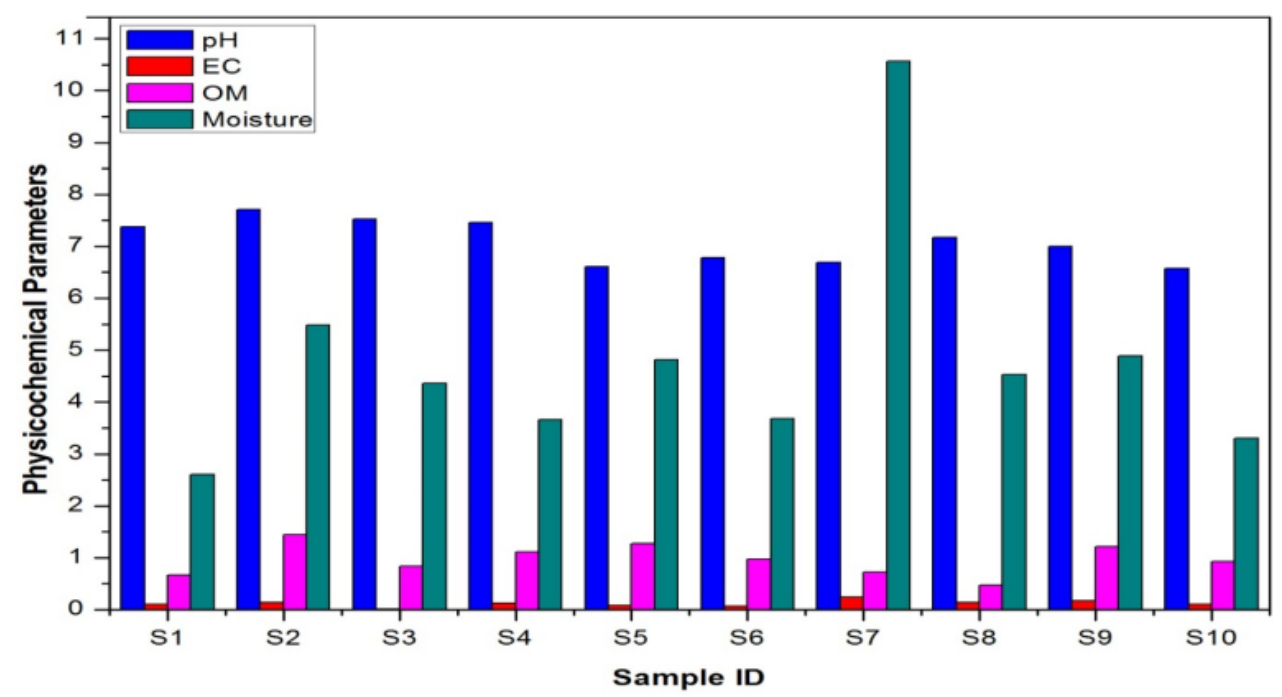

Figure 5. Variation of pH, EC, OM, and moisture in the investigated soil samples 
The alpha index has been calculated using the activity concentration of ${ }^{226} \mathrm{Ra}$ in the samples. The estimated alpha index values for the analyzed samples ranged from 0.0208 to 0.0643 with a mean value of 0.0409 that is lower than unity hence, the soil samples are safe for construction of houses. The excess lifetime cancer risk (ELCR) and annual gonadal dose equivalent (AGDE) are considered very important parameters for human health. As seen in Table 2 the AGDE values of soil samples varied between $0.095 \mathrm{mSv} / \mathrm{y}(\mathrm{S} 8)$ and $0.159 \mathrm{mSv} / \mathrm{y}$ (S2) with an average value of $0.128 \mathrm{mSv} / \mathrm{y}$. This result is lower than the permissible safety limit of $0.3 \mathrm{mSv} / \mathrm{y}$. The calculated of ELCR for outdoor exposure ranged from $0.585 \times 10^{-3}$ to $0.945 \times 10^{-3}$ with an average of $0.783 \times 10^{-3}$ which is greater than the worldwide recommended value of $0.290 \times 10^{-3}$ (UNSCEAR). The calculated hazard parameters of all samples are low comparing with the world average and the recommended safe limits. The values of these indices should be lower than unity to keep the radiation hazard insignificant. Building on these results of radiological hazard indices, one can indicate that the investigated soil samples are safe and can be used as building material without causing any significant radiological risk to humans.

\section{Physico-chemical characterization of the soil samples}

The basic Physico-chemical properties like $\mathrm{pH}$, conductivity, organic matter, moisture, etc., of the soil samples, were measured by employing standard methods and the results are listed in Table 3. In the current study, the $\mathrm{pH}$ values of soil samples varied in the ranges (6.57-7.71) with mean value 7.09 which are indicating that the analyzed soil samples were neutral. The variation of soil $\mathrm{pH}$ is given in Figure 5. The electrical conductivity was measured in term $\mathrm{mS} / \mathrm{cm}$ and results ranged from 0.01 to $0.24 \mathrm{mS} / \mathrm{cm}$ with a mean value of $0.12 \mathrm{mS} / \mathrm{cm}$ which means the soil samples under study are nonsaline. The electrical conductivity values for the selected samples are less than the other reported studies, which may be due to the absence of expected movable salts [26]. The variation of electrical conductivity in the soil samples given in Figure 5. The organic matter content in soils is medium (average 0.97 ) and ranges from $0.47 \%$ to $1.45 \%$. Natural organic matter (NOM) contains functional groups that can form complexes with metals, and these complexes can affect the physical and chemical properties of the affected metal or radionuclides. Complexation affects metal and radionuclide mobility, adsorption to soils and bioavailability [27]. In sandy soils, organic matter content is low when compared to other types of soil. A calcium carbonate value ranged from $1.20 \%$ to $6.25 \%$ which reveals that these soil samples are medium calcareous. The percentage of sand ranges from $67.44 \%$ to $88.28 \%$ with mean value $81.18 \%$, silt ranges from $5.09 \%$ to
$17.41 \%$ with mean value $9.24 \%$ and clay ranges from $0.08 \%$ to $17.61 \%$ with mean value $9.12 \%$. All soil samples of the study area show a high percentage of sand and this means that water can move easily and salinity in nature. Textural classes' analysis of the studied soil samples has been performed to classify the studied soils into their main types. Following the USDA soil texture classification [28-30], soil samples have these types: sandy, sandy loam and loam sand. The sand is the main soil type in the study area.

\section{Major and trace elements concentration in the soil}

The concentrations of major and trace elements were measured in the dry soil samples and results presented in Table 4. The following elements were detected in the samples: $\mathrm{Na}, \mathrm{K}, \mathrm{Ca}$, $\mathrm{Mg}, \mathrm{P}, \mathrm{N}, \mathrm{Fe}, \mathrm{Mn}, \mathrm{Zn}$, and $\mathrm{Cu}$ with different concentrations. The concentration of alkali metals ( $\mathrm{Na}$ and $\mathrm{K}$ ) varies in the ranges of $11200-88700$, and $33.80-2254.5 \mathrm{mg} / \mathrm{kg}$ with mean values of 49450 , and $455.35 \mathrm{mg} / \mathrm{kg}$, respectively. The average concentration of $\mathrm{Na}$ is greater than the recommended world average concentration of $25670 \mathrm{mg} / \mathrm{kg}$, while potassium is less than the recommended worldly average concentration of 28650 $\mathrm{mg} / \mathrm{kg}$. The concentration of alkaline earth metals ( $\mathrm{Ca}$ and $\mathrm{Mg}$ ) varied in the ranges of 20430-43040, and 43100-82300 mg/kg, with the corresponding mean values of 33568, and 63280 $\mathrm{mg} / \mathrm{kg}$, respectively, which is higher than the permissible values of 29450 , and $13510 \mathrm{mg} / \mathrm{kg}$, respectively [31]. The concentrations of $\mathrm{N}$ and $\mathrm{P}$ varied in the ranges of 3.39-29.03, and $14.28-265.25 \mathrm{mg} / \mathrm{kg}$ with mean values of 11.62 , and 82.15 $\mathrm{mg} / \mathrm{kg}$, respectively, which are lower than the recommended world average concentration 83, and $665 \mathrm{mg} / \mathrm{kg}$. The concentration of heavy metals ( $\mathrm{Fe}, \mathrm{Mn}, \mathrm{Zn}$, and $\mathrm{Cu}$ ) in the soil samples varies from 3.13-30.32, 6.87-81.14, 1.19-7.53, and $0.25-3.22 \mathrm{mg} / \mathrm{kg}$ with mean values of $13.11,26.71,3.79$, and $1.63 \mathrm{mg} / \mathrm{kg}$, respectively. Manganese concentrations in most samples were relatively high comparing to $\mathrm{Fe}, \mathrm{Zn}$, and $\mathrm{Cu}$ (Figure 6), where the maximum concentration was 81.14 $\mathrm{mg} / \mathrm{kg}$ at the sample S6 and the minimum concentration was $6.87 \mathrm{mg} / \mathrm{kg}$ at the sample S3. The average concentrations of Fe, $\mathrm{Mn}, \mathrm{Zn}$, and $\mathrm{Cu}$ are very much lower than the recommended world average concentration of $30890,558,67$, and $25 \mathrm{mg} / \mathrm{kg}$, respectively [32]. This indicated that the concentration of the elements in the study area is not harmful effects on the environment and human health. Among the elements detected, Magnesium had the highest mean concentration in the selected soil samples. From the results obtained in the study, it could be concluded that the concentration of different elements in the investigated soil samples is in the following decreasing order: $\mathrm{Mg}>\mathrm{Na}>\mathrm{Ca}>\mathrm{K}>\mathrm{N}>\mathrm{Mn}>\mathrm{Fe}>\mathrm{P}>\mathrm{Zn}>\mathrm{Cu}$. 
Table 4. The concentrations of the major and trace elements in the dry soil samples (mg/kg)

\begin{tabular}{|c|c|c|c|c|c|c|c|c|c|c|}
\hline \multirow{2}{*}{ Sample ID } & \multicolumn{6}{|c|}{ Major Elements } & \multicolumn{4}{|c|}{ Trace Elements } \\
\hline & $\mathbf{N a}$ & $\mathbf{K}$ & $\mathbf{C a}$ & Mg & $\mathbf{P}$ & $\mathbf{N}$ & $\mathbf{F e}$ & Mn & $\mathrm{Zn}$ & $\mathbf{C u}$ \\
\hline $\mathrm{S} 1$ & 79400 & 162.12 & 43040 & 54800 & 12.58 & 212.70 & 24.53 & 10.34 & 1.19 & 0.25 \\
\hline $\mathrm{S} 2$ & 74200 & 2254.5 & 26520 & 70500 & 29.03 & 51.25 & 6.80 & 68.45 & 2.89 & 2.34 \\
\hline $\mathrm{S} 3$ & 88700 & 98.75 & 33910 & 43100 & 7.62 & 14.28 & 3.13 & 6.87 & 5.36 & 0.84 \\
\hline $\mathrm{S} 4$ & 11200 & 71.29 & 30430 & 66600 & 6.17 & 30.71 & 7.06 & 15.25 & 1.56 & 1.21 \\
\hline S5 & 15500 & 527.5 & 27830 & 70500 & 3.39 & 265.25 & 30.32 & 8.89 & 1.90 & 1.86 \\
\hline S6 & 34350 & 33.80 & 20430 & 62700 & 4.36 & 39.28 & 5.67 & 81.14 & 3.87 & 1.73 \\
\hline S7 & 64950 & 528 & 42170 & 50900 & 6.41 & 61.91 & 4.14 & 12.86 & 7.53 & 0.92 \\
\hline S8 & 53230 & 711.5 & 34030 & 82300 & 18.99 & 49.22 & 16.34 & 22.02 & 4.87 & 3.22 \\
\hline S9 & 44530 & 104.54 & 41210 & 59800 & 11.36 & 52.95 & 11.56 & 28.98 & 6.56 & 2.76 \\
\hline S10 & 28440 & 61.53 & 36110 & 71600 & 16.27 & 43.93 & 21.54 & 12.33 & 2.12 & 1.13 \\
\hline Minimum & 11200 & 33.80 & 20430 & 43100 & 3.39 & 14.28 & 3.13 & 6.87 & 1.19 & 0.25 \\
\hline Maximum & 88700 & 2254.5 & 43040 & 82300 & 29.03 & 265.25 & 30.32 & 81.14 & 7.53 & 3.22 \\
\hline Mean & 49450 & 455.35 & 33568 & 63280 & 11.62 & 82.15 & 13.11 & 26.71 & 3.79 & 1.63 \\
\hline Background values [33] & 9600 & 26600 & 22100 & 15000 & 700 & - & 47200 & 850 & 95 & 45 \\
\hline
\end{tabular}

Table 5. Geo-accumulation index $\left(I_{\text {geo }}\right)$ for the measured elements in the soil samples

\begin{tabular}{|c|c|c|c|c|c|c|c|c|c|c|}
\hline Sample ID & $\mathrm{Na}$ & $\mathbf{K}$ & $\mathbf{C a}$ & Mg & $\mathbf{P}$ & $\mathbf{N}$ & $\mathrm{Fe}$ & Mn & $\mathbf{Z n}$ & $\mathbf{C u}$ \\
\hline $\mathrm{S} 1$ & 2.46 & -7.94 & -0.38 & 1.28 & -6.38 & - & -11.49 & -6.95 & -6.90 & -8.08 \\
\hline $\mathrm{S} 2$ & 2.37 & -4.15 & -0.32 & 1.65 & -5.18 & - & -13.34 & -4.22 & -5.62 & -4.85 \\
\hline S3 & 2.62 & -8.66 & 0.03 & 0.94 & -7.11 & - & -14.47 & -7.54 & -4.73 & -6.33 \\
\hline $\mathrm{S} 4$ & -0.36 & -9.13 & -0.12 & 1.57 & -7.41 & - & -13.29 & -6.39 & -6.51 & -5.80 \\
\hline S5 & 0.11 & -6.24 & -0.25 & 1.65 & -8.27 & - & -11.19 & -7.16 & -6.23 & -5.18 \\
\hline S6 & 1.25 & -10.21 & -0.70 & 1.48 & -7.91 & - & -13.61 & -3.97 & -5.20 & -5.29 \\
\hline S7 & 2.17 & -6.24 & 0.35 & 1.18 & -7.36 & - & -14.06 & -6.63 & -4.24 & -6.20 \\
\hline S8 & 1.89 & -5.81 & 0.04 & 1.87 & -5.79 & - & -12.08 & -5.86 & -4.87 & -4.39 \\
\hline S9 & 1.63 & -8.58 & 0.31 & 1.41 & -6.53 & - & -12.58 & -5.46 & -4.44 & -4.61 \\
\hline S10 & 0.98 & -9.34 & 0.12 & 1.67 & -6.01 & - & -11.68 & -6.69 & -6.07 & -5.90 \\
\hline Mean & 1.51 & -7.63 & -0.09 & 1.47 & -6.80 & - & -12.78 & -6.09 & -5.48 & -5.66 \\
\hline Range & $0.11-2.62$ & $4.15-10.21$ & $0.03-0.70$ & $0.94-1.87$ & $5.18-8.27$ & - & $11.19-14.47$ & $3.97-7.54$ & $4.24-6.90$ & $4.39-8.08$ \\
\hline
\end{tabular}

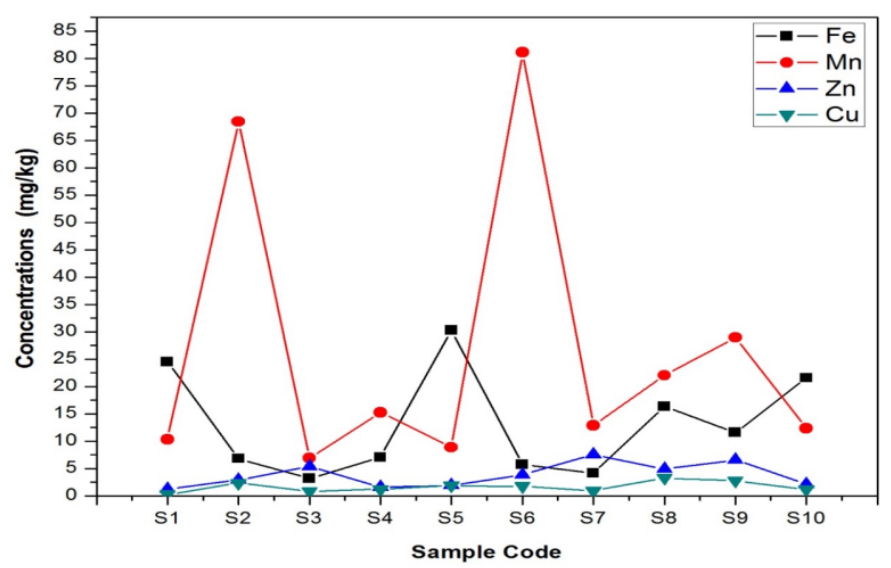

Figure 6. Concentration of heavy metals in the soil sample

\section{Pollution risk assessment}

Noteworthy that, heavy metals have great ecological importance for their toxicity and tendency to accumulate in soils. The geo-accumulation index $\left(\mathrm{I}_{\mathrm{geo}}\right)$, contamination factor (CF) and degree of contamination (Cd), pollution load index (PLI) and potential ecological risk index (RI) were calculated to evaluate the pollution risks due to the elements in the soil

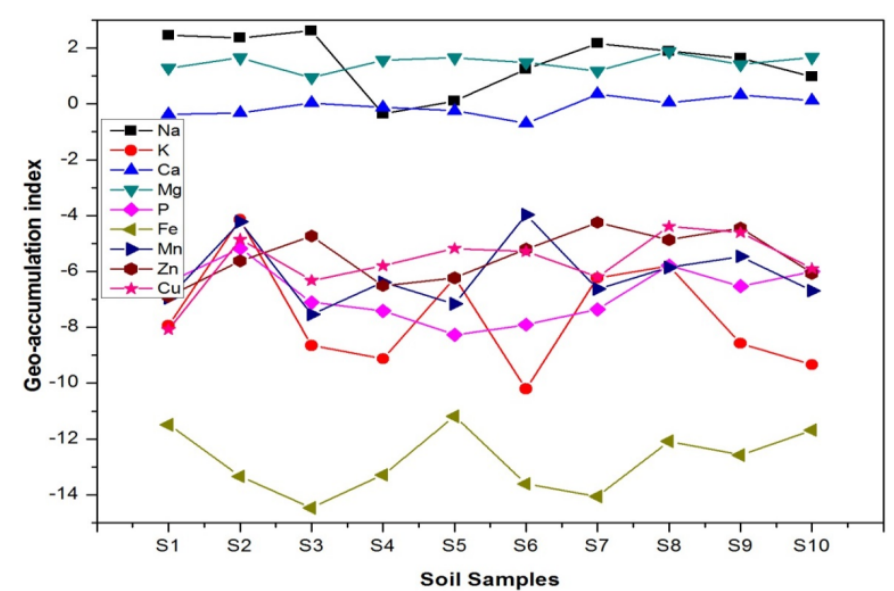

Figure 7. Variation of $I_{g e o}$ index for elements in the investigated soil samples

samples. For optimal interpretation of geochemical data, an appropriate choice of background values is essential. Many studies use the average shale values or the average crustal abundance data as reference baselines. The geo-accumulation index for the selected samples was calculated and given in Table 5. The values of the geo-accumulation index are ranges as the following: (from 0.11 to 2.62 ) for $\mathrm{Na},(-4.15$ to -10.21 ) 
for $\mathrm{K},(0.03$ to -0.70$)$ for $\mathrm{Ca},(0.94$ to 1.87$)$ for $\mathrm{Mg},(-5.18$ to $-8.27)$ for $\mathrm{P},(-11.19$ to -14.47$)$ for $\mathrm{Fe},(-3.97$ to -7.54$)$ for $\mathrm{Mn},(-4.24$ to -6.90$)$ for $\mathrm{Zn}$, and $(-4.39$ to -8.08$)$ for $\mathrm{Cu}$. The average $\mathrm{I}_{\text {geo }}$ values of $\mathrm{Na}(1.51)$ and $\mathrm{Mg}$ (1.47) suggesting that, the sampling locations are moderately contaminated $\left(1 \leq \mathrm{I}_{\mathrm{geo}} \leq\right.$ 2 ), with these elements. The average contamination degree of these elements decreases in the following order: $(\mathrm{Na}>\mathrm{Mg}>\mathrm{Ca}>\mathrm{Zn}>\mathrm{Cu}>\mathrm{Mn}>\mathrm{P}>\mathrm{K}>\mathrm{Fe})$. The average values of $\mathrm{I}_{\text {geo }}$ are generally noticed lower than unity except for $\mathrm{Na}$ and $\mathrm{Mg}$; indicating that the investigated study area is not polluted. Variation in $I_{\text {geo }}$ indices values for the measured elements in the samples is shown in Figure 7.

The contamination factors of the elements obtained in the studied soil samples are given in Table 6. The results of CF are ranges as the following: (1.167-9.239) for $\mathrm{Na},(0.001-0.085)$ for $\mathrm{K},(0.924-1.948)$ for $\mathrm{Ca},(2.873-5.487)$ for $\mathrm{Mg}$, (0.005$0.041)$ for $\mathrm{P},(0.008-0.095)$ for $\mathrm{Mn},(0.013-0.079)$ for $\mathrm{Zn}$, and (0.006-0.072) for $\mathrm{Cu}$. The average contamination factors of major elements are $\mathrm{Na}$ (5.151), Ca (1.519), and Mg (4.219). This indicates moderate contamination and therefore the level of contamination is considerable with these elements. Furthermore, the mean values of $\mathrm{CF}$ for elements $\mathrm{K}, \mathrm{P}, \mathrm{Mn}, \mathrm{Zn}$, and $\mathrm{Cu}$ in the samples are less than one, therefore; the soil samples could also be classified as lowly contaminated with these elements. Generally, the contamination factors behavior like the geo-accumulation index. The contamination degree $\left(\mathrm{C}_{\mathrm{d}}\right)$ vales in sampling points $\mathrm{S} 1$ (13.927), S2 (13.918), S3 (13.744), S7 (12.21), and S8 (12.775) suggests that the selected soil samples are considered as considerable contaminate degree and moderate contamination degree for sampling (S4, S5, S6, $\mathrm{S} 9, \mathrm{~S} 10)$. The average contamination degree $\left(\mathrm{C}_{\mathrm{d}}\right)$ for all elements is 11.030 indicates that the soil samples are considered of moderate contamination degree which indicating anthropogenic pollution. The results of PLI ranged from 0.0790.257 with a mean of 0.134 , thus indicating that the study area is not contaminated. The PLI values for all samples are lower than unity indicating the role of external discrete sources and agricultural activities of soil pollution. The results of pollution risk assessment in the present study indicate not probable environmental pollution, particularly with heavy metals.

Assessment of the ecological risk due to heavy metals in the investigated soils was done and presented in Table 7 and Figure 8. It had been found that the average values of ecological risk factors $\mathrm{E}_{\mathrm{r}}^{\mathrm{i}}$ of $\mathrm{Mn}, \mathrm{Zn}$, and $\mathrm{Cu}$ are $<40$ indicating that soils are a low potential ecological hazard. The mean values of $E_{r}^{i}$ ranked in the formed order $(\mathrm{Mn}<\mathrm{Zn}<\mathrm{Cu})$. Potential ecological risk index (RI) of $\mathrm{Mn}, \mathrm{Zn}$ and $\mathrm{Cu}$ were less than 95 indicating that these metals posed a low potential ecological risk to the environment. The values of a potential ecological risk index for the selected sample sites can be classified as low risk to the environment. Hence, soils under study area show no risk to the environment due to these metals.

\section{Correlation analysis}

To evaluate the correlations between activity concentrations of radionuclides and the radiological parameters, as well as with Physico-chemical properties and elemental composition of the soil samples, Pearson linear correlation coefficient was determined. Pearson product-moment correlation coefficients were calculated by the linear fit method. The obtained correlation matrixes were presented in Tables 8-10. A positive correlation was observed between radium and thorium with correlation coefficients of $(r=0.188)$ due to ${ }^{226} \mathrm{Ra}$ and ${ }^{232} \mathrm{Th}$ occur in the same decay series. ${ }^{40} \mathrm{~K}$ shows that insignificant correlation $(r=-0.006),(r=-0.196)$ with ${ }^{226} \mathrm{Ra}$ and ${ }^{232} \mathrm{Th}$ due to potassium occur in different decay series. There exists a very good correlation between ${ }^{226} \mathrm{Ra},{ }^{232} \mathrm{Th}$ with absorbed dose in air with correlation coefficients $(r=0.525),(r=0.832)$. All the calculated radiological parameters have a strong correlation with ${ }^{232} \mathrm{Th}$ and ${ }^{226} \mathrm{Ra}$, while there is a weak correlation with ${ }^{40} \mathrm{~K}$. This indicates that the natural radioactivity in the soils depends on the concentration of radium and thorium.

Table 6. Contamination factor (CF), degree of contamination $\left(C_{d}\right)$ and pollution load index (PLI) of elements in the investigated soil samples

\begin{tabular}{|c|c|c|c|c|c|c|c|c|c|c|}
\hline \multirow{2}{*}{ Sample ID } & \multicolumn{8}{|c|}{ Contamination Factor $(\mathrm{CF})$} & \multirow{2}{*}{$\mathbf{C}_{\mathrm{d}}$} & \multirow{2}{*}{ PLI } \\
\hline & $\mathrm{Na}$ & $\mathbf{K}$ & $\mathrm{Ca}$ & Mg & $\mathbf{P}$ & Mn & $\mathbf{Z n}$ & $\mathrm{Cu}$ & & \\
\hline S1 & 8.271 & 0.006 & 1.948 & 3.653 & 0.018 & 0.012 & 0.013 & 0.006 & 13.927 & 0.094 \\
\hline $\mathrm{S} 2$ & 7.729 & 0.085 & 1.200 & 4.700 & 0.041 & 0.081 & 0.030 & 0.052 & 13.918 & 0.257 \\
\hline $\mathrm{S} 3$ & 9.239 & 0.004 & 1.534 & 2.873 & 0.011 & 0.008 & 0.056 & 0.019 & 13.744 & 0.105 \\
\hline $\mathrm{S} 4$ & 1.167 & 0.003 & 1.377 & 4.440 & 0.009 & 0.018 & 0.016 & 0.027 & 7.057 & 0.079 \\
\hline S5 & 1.615 & 0.020 & 1.259 & 4.700 & 0.005 & 0.010 & 0.020 & 0.041 & 7.670 & 0.097 \\
\hline S6 & 3.578 & 0.001 & 0.924 & 4.180 & 0.006 & 0.095 & 0.041 & 0.038 & 8.863 & 0.103 \\
\hline S7 & 6.766 & 0.020 & 1.908 & 3.393 & 0.009 & 0.015 & 0.079 & 0.020 & 12.21 & 0.144 \\
\hline S8 & 5.545 & 0.027 & 1.540 & 5.487 & 0.027 & 0.026 & 0.051 & 0.072 & 12.775 & 0.206 \\
\hline S9 & 4.639 & 0.004 & 1.865 & 3.987 & 0.016 & 0.034 & 0.069 & 0.061 & 10.675 & 0.154 \\
\hline S10 & 2.963 & 0.002 & 1.634 & 4.773 & 0.023 & 0.015 & 0.022 & 0.025 & 9.457 & 0.098 \\
\hline Range & $\begin{array}{l}1.167- \\
-9.239\end{array}$ & $\begin{array}{l}0.001- \\
-0.085\end{array}$ & $\begin{array}{l}0.924- \\
-1.948\end{array}$ & $\begin{array}{l}2.873- \\
-5.487\end{array}$ & $\begin{array}{l}0.005- \\
-0.041\end{array}$ & $\begin{array}{l}0.008- \\
-0.095\end{array}$ & $\begin{array}{l}0.013- \\
-0.079\end{array}$ & $\begin{array}{l}0.006- \\
-0.072\end{array}$ & $\begin{array}{c}7.057- \\
-13.927\end{array}$ & $\begin{array}{l}0.079- \\
-0.257\end{array}$ \\
\hline Mean & 5.151 & 0.017 & 1.519 & 4.219 & 0.017 & 0.031 & 0.040 & 0.036 & 11.030 & 0.134 \\
\hline
\end{tabular}


Table 7. Potential ecological risk factor and potential ecological risk index in soils

\begin{tabular}{ccccc}
\hline \hline \multirow{2}{*}{ Sample ID } & \multicolumn{3}{c}{ Ecological risk factor $\left(\mathbf{E}_{\mathbf{r}}^{\mathbf{i}}\right)$} & \multirow{2}{*}{ RI } \\
\cline { 2 - 4 } & Mn & $\mathbf{Z n}$ & $\mathbf{C u}$ & \\
\hline S1 & 0.012 & 0.013 & 0.03 & 0.055 \\
S2 & 0.081 & 0.030 & 0.26 & 0.371 \\
S3 & 0.008 & 0.056 & 0.095 & 0.159 \\
S4 & 0.018 & 0.016 & 0.135 & 0.169 \\
S5 & 0.010 & 0.020 & 0.205 & 0.235 \\
S6 & 0.095 & 0.041 & 0.190 & 0.326 \\
S7 & 0.015 & 0.079 & 0.100 & 0.194 \\
S8 & 0.026 & 0.051 & 0.360 & 0.437 \\
S9 & 0.034 & 0.069 & 0.305 & 0.408 \\
S10 & 0.015 & 0.022 & 0.150 & 0.187 \\
Mean & 0.031 & 0.040 & 0.183 & 0.254 \\
\hline \hline
\end{tabular}

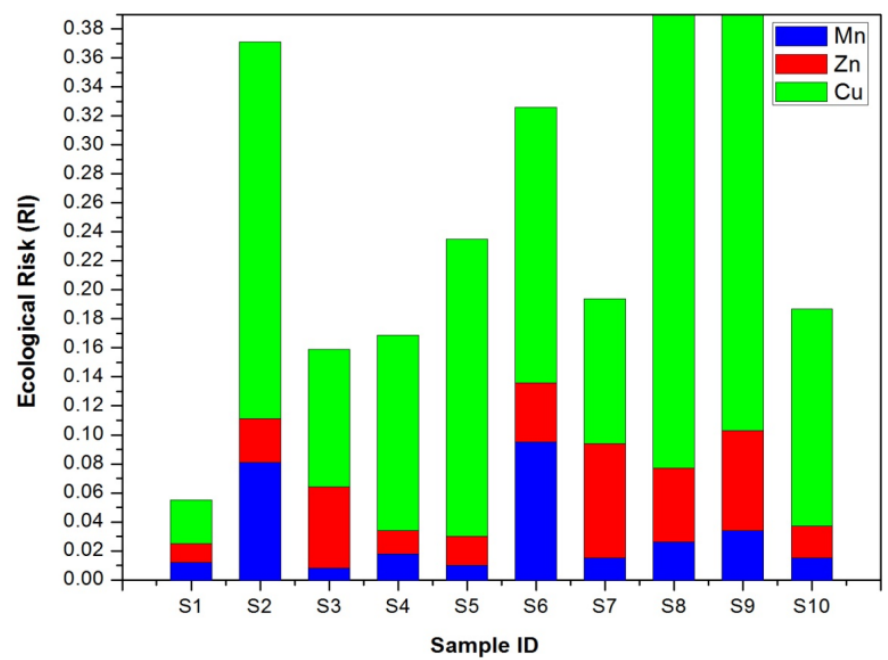

Figure 8. Potential ecological risk index (RI) of heavy metals in soil samples

Table 8. The Pearson correlation between radioactive variables in soil samples

\begin{tabular}{|c|c|c|c|c|c|c|c|c|c|c|c|}
\hline Variables & ${ }^{226} \mathbf{R a}$ & ${ }^{232} \mathrm{Th}$ & ${ }^{40} K$ & $D_{a b}$ & $\mathbf{R a}_{\mathrm{eq}}$ & $\mathbf{H}_{\text {in }}$ & $\mathbf{H}_{\mathrm{ex}}$ & $\overline{\mathbf{I}_{\gamma}}$ & AEDE & ELCR & $\mathbf{I}_{\alpha}$ \\
\hline${ }^{226} \mathrm{Ra}$ & 1.00 & - & - & - & - & - & - & - & - & - & - \\
\hline${ }^{232} \mathrm{Th}$ & 0.188 & 1.00 & - & - & - & - & - & - & - & - & - \\
\hline${ }^{40} \mathrm{~K}$ & -0.006 & -0.196 & 1.00 & - & - & - & - & - & - & - & - \\
\hline $\mathrm{D}_{\mathrm{ab}}$ & 0.525 & 0.832 & 0.249 & 1.00 & - & - & - & - & - & - & - \\
\hline $\mathrm{Ra}_{\mathrm{eq}}$ & 0.512 & 0.88 & 0.163 & 0.996 & 1.00 & - & - & - & - & - & - \\
\hline $\mathrm{H}_{\mathrm{in}}$ & 0.708 & 0.774 & 0.133 & 0.970 & 0.969 & 1.00 & - & - & - & - & - \\
\hline $\mathrm{H}_{\mathrm{ex}}$ & 0.513 & 0.875 & 0.163 & 0.999 & 1.00 & 0.973 & 1.00 & - & - & - & - \\
\hline $\mathrm{I}_{\gamma}$ & 0.491 & 0.850 & 0.242 & 0.999 & 0.997 & 0.960 & 1.00 & 1.00 & - & - & - \\
\hline AEDE & 0.486 & 0.841 & 0.259 & 1.00 & 0.993 & 1.00 & 0.996 & 0.998 & 1.00 & - & - \\
\hline ELCR & 0.486 & 0.840 & 0.259 & 0.997 & 0.992 & 0.956 & 0.993 & 0.997 & 0.999 & 1.00 & - \\
\hline $\mathrm{I}_{\alpha}$ & 0.999 & 0.190 & -0.005 & 0.526 & 0.513 & 0.709 & 0.514 & 0.493 & 0.487 & 0.488 & 1.00 \\
\hline
\end{tabular}

Table 9. Correlation coefficient matrix of radionuclides and Physico-chemical properties

\begin{tabular}{|c|c|c|c|c|}
\hline Variables & 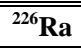 & 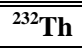 & ${ }^{4{ }^{40} K}$ & $\mathbf{R a}_{\mathrm{eq}}$ \\
\hline $\mathrm{pH}$ & 0.70 & 0.33 & 0.11 & 0.57 \\
\hline $\mathrm{EC}$ & -0.16 & -0.54 & 0.29 & -0.43 \\
\hline Organic matter & 0.23 & 0.58 & 0.05 & 0.60 \\
\hline Moisture & -0.42 & -0.50 & 0.32 & -0.47 \\
\hline Sand $(\%)$ & 0.08 & 0.25 & -0.33 & 0.13 \\
\hline Silt $(\%)$ & 0.30 & -0.25 & 0.42 & 0.03 \\
\hline Clay (\%) & -0.38 & -0.13 & 0.05 & -0.23 \\
\hline $\mathrm{Na}$ & 0.37 & -0.10 & 0.05 & 0.06 \\
\hline K & 0.64 & 0.02 & 0.03 & 0.25 \\
\hline $\mathrm{Ca}$ & -0.06 & -0.41 & 0.42 & -0.24 \\
\hline $\mathrm{Mg}$ & 0.37 & -0.23 & -0.12 & -0.11 \\
\hline $\mathrm{P}$ & 0.83 & -0.08 & 0.20 & 0.28 \\
\hline $\mathrm{N}$ & 0.06 & 0.18 & -0.52 & 0.01 \\
\hline $\mathrm{Fe}$ & 0.19 & 0.02 & -0.31 & -0.02 \\
\hline Mn & 0.17 & 0.22 & -0.46 & 0.10 \\
\hline $\mathrm{Zn}$ & -0.37 & -0.68 & 0.30 & -0.62 \\
\hline $\mathrm{Cu}$ & 0.33 & -0.49 & -0.05 & -0.33 \\
\hline
\end{tabular}


Table 10. Correlation coefficient matrix for elemental concentration and Physico-chemical properties of the soil samples

\begin{tabular}{|c|c|c|c|c|c|c|c|c|c|c|}
\hline Variables & $\mathbf{N a}$ & $\mathbf{K}$ & $\mathrm{Ca}$ & Mg & $\mathbf{P}$ & $\mathbf{N}$ & $\mathbf{F e}$ & Mn & Zn & $\mathrm{Cu}$ \\
\hline $\mathrm{Na}$ & 1.00 & - & - & - & - & - & - & - & - & - \\
\hline $\mathrm{K}$ & 0.32 & 1.00 & - & - & - & - & - & - & - & - \\
\hline $\mathrm{Ca}$ & 0.38 & -0.27 & 1.00 & - & - & - & - & - & - & - \\
\hline $\mathrm{Mg}$ & -0.54 & 0.34 & -0.37 & 1.00 & - & - & - & - & - & - \\
\hline $\mathrm{P}$ & 0.39 & 0.76 & 0.02 & 0.45 & 1.00 & - & - & - & - & - \\
\hline $\mathrm{N}$ & -0.13 & -0.01 & 0.11 & 0.07 & -0.22 & 1.00 & - & - & - & - \\
\hline $\mathrm{Fe}$ & -0.32 & -0.12 & 0.16 & 0.42 & -0.01 & 0.82 & 1.00 & - & - & - \\
\hline $\mathrm{Mn}$ & 0.01 & 0.44 & -0.67 & 0.22 & 0.30 & -0.31 & -0.40 & 1.00 & - & - \\
\hline $\mathrm{Zn}$ & 0.36 & -0.04 & 0.33 & -0.38 & -0.11 & -0.46 & -0.57 & 0.02 & 1.00 & - \\
\hline $\mathrm{Cu}$ & -0.21 & 0.40 & -0.28 & 0.66 & 0.40 & -0.20 & -0.01 & 0.39 & 0.28 & 1.00 \\
\hline $\mathrm{pH}$ & 0.53 & 0.41 & -0.04 & -0.15 & 0.46 & -0.24 & -0.38 & 0.12 & -0.16 & -0.01 \\
\hline $\mathrm{EC}$ & -0.02 & 0.26 & 0.47 & 0.12 & 0.19 & -0.08 & -0.15 & -0.02 & 0.43 & 0.21 \\
\hline Organic matter & -0.33 & 0.40 & -0.45 & 0.12 & 0.12 & 0.08 & -0.03 & 0.39 & -0.25 & 0.22 \\
\hline Moisture & 0.21 & 0.29 & 0.26 & -0.26 & -0.08 & -0.13 & -0.39 & -0.06 & 0.70 & 0.03 \\
\hline Sand $(\%)$ & -0.18 & -0.58 & -0.08 & 0.09 & -0.20 & 0.23 & 0.52 & -0.19 & -0.48 & -0.16 \\
\hline Silt (\%) & 0.24 & 0.74 & 0.18 & 0.20 & 0.69 & -0.25 & -0.23 & 0.25 & 0.28 & 0.29 \\
\hline Clay (\%) & 0.03 & 0.21 & -0.05 & -0.31 & -0.33 & -0.07 & -0.54 & 0.10 & 0.44 & 0.00 \\
\hline $\mathrm{CaCO}_{3}$ & 0.27 & 0.36 & 0.15 & -0.24 & 0.16 & -0.37 & -0.57 & -0.13 & 0.16 & -0.30 \\
\hline
\end{tabular}

The correlation between physicochemical properties and radionuclides in soils were calculated and presented in Table $\mathbf{9 .}$ It can be noted that all the radionuclides studies in the present study are positively correlated with the $\mathrm{pH}$ and organic matter content of the soil. The positive sign on all the correlation coefficient values indicates that higher concentrations of radionuclides occur at higher $\mathrm{pH}$ values. Where strong correlation between $\mathrm{pH}$ and ${ }^{226} \mathrm{Ra}$ was observed $(\mathrm{r}=0.70)$. A significant correlation with correlation coefficients of 0.58 , 0.23 and 0.60 , respectively were observed between ${ }^{232} \mathrm{Th}$, ${ }^{226} \mathrm{Ra}$, and Raeq activities with organic matter content in the soil samples. This suggests that higher activity concentration occurs at higher organic matter content and indicates the sequestering adsorption of these radionuclides on organic matter. Radium is positively correlated with silt $(\mathrm{r}=0.30)$, sand $(\mathrm{r}=0.08)$ and negatively correlated with clay $(\mathrm{r}=-0.38)$. Similarly, thorium is positive correlated with sand $(r=0.25)$, and negatively correlated with silt $(\mathrm{r}=-0.25)$, clay $(\mathrm{r}=-0.13)$. The concentration of potassium is positively correlated with silt $(r=0.42)$, clay $(r=0.05)$ and negatively correlated with sand $(r$ $=-0.33)$. The best correlation obtained between silt content and ${ }^{40} \mathrm{~K},{ }^{226} \mathrm{Ra}$ activity concentrations $(\mathrm{r}=0.42),(\mathrm{r}=0.30)$. ${ }^{226} \mathrm{Ra}$ showed a positively significant correlation with $\mathrm{Na}, \mathrm{K}$, $\mathrm{Mg}, \mathrm{P}$, and $\mathrm{Cu}$, whereas ${ }^{232} \mathrm{Th}$ showed a negative correlation with $\mathrm{Ca}, \mathrm{Zn}$, and $\mathrm{Cu}$ with significance level. ${ }^{40} \mathrm{~K}$ exhibited a negative correlation with $\mathrm{N}, \mathrm{Fe}$, and $\mathrm{Mn}$ and positive correlation with $\mathrm{Ca}$ and $\mathrm{Zn}$ with a significance level. Both the radionuclides ${ }^{226} \mathrm{Ra}$ and ${ }^{232} \mathrm{Th}$ are weakly positively correlated with $\mathrm{N}, \mathrm{Fe}$, and $\mathrm{Mn}$, and positively weakly correlation between ${ }^{40} \mathrm{~K}$ with $\mathrm{Na}, \mathrm{K}$, and $\mathrm{P}$. There are moderate or strong correlations between $\mathrm{Zn}$, and $\mathrm{Cu}$, with ${ }^{226} \mathrm{Ra},{ }^{232} \mathrm{Th}$, and Raeq. These correlations among metals and radionuclides suggest their common origin. Also, there are observed moderate correlations between the radionuclide ${ }^{40} \mathrm{~K}$ with heavy metals
$\mathrm{Fe}, \mathrm{Mn}$, and $\mathrm{Zn}$ at the significance level. Generally, the positive correlation analysis indicates that concentrations of radium and thorium mainly contribute to radioactive pollution in the soil, while the negative correlation among the variables indicates that physicochemical properties do not contribute in radioactive soil pollution of the study area.

The elemental concentrations were tested for any correlation with the physicochemical properties of the soils and presented in Table 10. The higher correlation coefficient (r) values suggest that chemical and physical factors control the element associations in the parent material and the soil-forming processes. Most of the elements were significantly correlated with each other, except for Nitrogen. The copper in the soil samples is significantly correlated with $\mathrm{K}, \mathrm{Ca}, \mathrm{Mg}, \mathrm{P}, \mathrm{Mn}$, and $\mathrm{Zn}$ which suggests that $\mathrm{Cu}$ is associated mostly with the mineral phase in the soils. The soil $\mathrm{pH}$ did not show a significant correlation with $\mathrm{Ca}, \mathrm{Mg}, \mathrm{N}, \mathrm{Mn}, \mathrm{Zn}$, and $\mathrm{Cu}$. This indicates that increasing $\mathrm{pH}$ reduces the availability of $\mathrm{Ca}, \mathrm{Mg}$, $\mathrm{Fe}, \mathrm{Mn}, \mathrm{Zn}$, and $\mathrm{Cu}$. Electrical conductivity showed a positive correlation with $\mathrm{K}, \mathrm{Ca}$, and $\mathrm{Zn}$ with significant correlation coefficients, however, it was a non-significant correlation with all other elements. This indicates that a decrease in soluble salts in the soils and no dilution effects of minerals. The organic matter content was a significant correlation with $\mathrm{Na}, \mathrm{K}$, $\mathrm{Ca}$, and $\mathrm{Mn}$. This is because of the strong absorption of the transition metals by the soil organic matter. There exists strong positive correlation between silt, $\mathrm{K}(\mathrm{r}=0.74)$ and silt, $\mathrm{P}(\mathrm{r}=$ 0.69).

\section{Conclusion}

The concentrations of primordial radionuclide and physicochemical properties in the soil samples have been determined using gamma-ray spectrometry and by different analytical techniques. The radioactivity level has been found 
below the permissible limits of 35, 30, and $400 \mathrm{~Bq} / \mathrm{kg}$ for ${ }^{226} \mathrm{Ra}$, ${ }^{232} \mathrm{Th}$, and ${ }^{40} \mathrm{~K}$ respectively (UNSCEAR, 2000). The difference observed in the activities from ${ }^{226} \mathrm{Ra},{ }^{232} \mathrm{Th}$ and ${ }^{40} \mathrm{~K}$ in the samples, maybe due to the different soil physicochemical properties, such as $\mathrm{pH}$, organic matter, soil texture, geological formation, moisture, and geochemical composition for soil samples. The average value of Raeq is $40.5023 \mathrm{~Bq} \mathrm{~kg}^{-1}$ which is below the recommended safe limit value of $370 \mathrm{~Bq} \mathrm{~kg}^{-1}$ for the public. The absorbed dose rate in air is well below the permissible limits $\left(56 \mathrm{nGy} \mathrm{h}^{-1}\right)$. The calculated annual effective dose is lower than the average world recommended level of 1 $\mathrm{mSv}^{-1}$ for the individual member of the public. The values of the health hazard indices such as external hazard index, internal hazard index, gamma index and alpha index have been estimated and found to be less than the recommended safe levels i.e. unity., thus quite safe from radiation protection point of view and thus can be well utilized for the construction material without causing any significant radiological threat to the population. The concentration of different elements in the soils was measured as well. All elements were below the environmental background values, except $\mathrm{Na}, \mathrm{Ca}$, and $\mathrm{Mg}$, while, their mean concentration was as following order: $\mathrm{Mg}>\mathrm{Na}>\mathrm{Ca}>\mathrm{K}>\mathrm{N}>\mathrm{Mn}>\mathrm{Fe}>\mathrm{P}>\mathrm{Zn}>\mathrm{Cu}$, respectively.

Correlation analysis was performed to quantify the dependence of radionuclide activity concentrations with soil variables. The results of the correlation analysis showed varying trends of linear relationships between the natural radionuclides and the elemental compositions of the soils.

The geo-accumulation index $\left(\mathrm{I}_{\text {geo }}\right)$, contamination factor (CF), degree of contamination (Cd), pollution load index (PLI), and potential ecological risk index (RI) were calculated to determine the contamination of elements in the soils. The geoaccumulation index values showed that soil samples were uncontaminated with the measured elements. Based on the contamination factor and contamination degree, the study area belongs to under a moderate contamination degree for major elements and low contamination degree for elements. The pollution load index is lower than unity which indicates the status of no clear pollution. The potential ecological risk index values for the selected samples follow the classification of low contamination risk to the environment. The obtained results from the pollution indices ( $\mathrm{I}_{\mathrm{geo}}, \mathrm{CF}, \mathrm{Cd}, \mathrm{PLI}$, and RI) showed that the soils of the study area have minimal contamination by elements and therefore, do not pose significant ecological risk. Generally, the results showed minimal contamination of the soils by elements; however, community-based awareness on the issue of environmental contamination, its health impacts, and possible prevention, is advisable. The present study suggests that these indices are useful tools for the identification of anthropogenic sources of soil contamination. The soil samples used in the present study are exempted from all the restrictions concerning radioactivity thus, these soil samples are safe to be used for building construction.

\section{Acknowledgements}

The authors would like to thank the editor and reviewers of the Polish Journal of Medical Physics and Engineering (Pol J Med Phys Eng) for their careful reading of our manuscript and their useful comments and suggestions.

\section{References}

[1] UNSCEAR. United Nations Scientific Committee on the Effects of Atomic Radiation. In: Sources and Effects of Ionizing Radiation, Vol. I. United Nations, New York. 2000.

[2] Al-khawlany AH, Khan AR, Pathan JM, et al. Measurement of activity concentration levels of radionuclides and associated hazard indices in soil samples collected from Aurangabad, Maharashtra-India. Int J Sci Eng Res. 2017; 8(7):1586-1593.

[3] Al-Khawlany AH, Khan AR, Pathan JM. Review on studies in natural background radiation. Radiat Prot Environ. 2018; 41(4):215222.

[4] Trachenko K, Dove MT, Geisler T, et al. Radiation damage effects and percolation theory. J Phys Condens Matter. 2004;16(27):S2623-S2627.

[5] Baca TE, Florkowski T. The environmental challenges of nuclear disarmament. Springer Science \& Business Media. Vol. $29 ; 2000$.

[6] EPA. Edition of the Drinking Water Standards and Health Advisories. Environmental Protection Agency: Washington; 2006.

[7] Al-Khawlany AH, Khan AR, Pathan JM. Assessment of natural radioactivity levels and associated radiological hazards for some environmental soil and rock samples from outskirts of Aurangabad, India using gamma-ray spectrometry. Int J Innovative Res Sci Eng Technol. 2017; 6(8):16592-16604.

[8] Malanca A, Pessina V, Dallara G. Assessment of natural radioactivity in the Brazilian state of Rio Grande. Health Phys. 1993; 65(3):298-302.

[9] Patil VD, Ismail S, Kausadikar HK. Practical Manual-Soil Quality Indicators. 1st ed. Published on behalf of Department of Soil Science \& Agricultural Chemistry, Marathwada Krishi Vidyapeeth Parbhani-431402, India; 2012. pp. 9-80.

[10] Sanjay K, Ketterings QM. Laboratory Manual Soil, Plant and Water Analysis. Department of Animal Science, College of Agriculture and Life Sciences, Cornell University; 2017. pp.1-50. 
[11] Walkley AJ, Black IA. Estimation of soil organic carbon by the chromic acid titration method. Soil Sci. 1934;37:29-38.

[12] Jankovic M, Todorovic D, Savanovic M. Radioactivity measurements in rock samples collected in the Republic of Srpska. Radiat Meas. 2008;43:1448-1452.

[13] Veiga RGN, Sanche SR, Anjos M, et al. Measurement of natural radioactivity in Brazillian beach sands. Radiat Meas. 2006;41:189196.

[14] Powell BA, Hughes LD, Soreefan AM, et al. Elevated concentrations of primordial radionuclides in sediments from the Reedy River and surrounding creeks in Simpsonville, South Carolina. J Environ Radioact. 2007;94:121-128.

[15] Beretka J, Mathew PJ. Natural radioactivity of Australian building materials, industrial wastes and by-products. Health Phys. 1985;48:87-95.

[16] NEA-OECD. Nuclear Energy Agency. Exposure to Radiation from Natural Radioactivity in Building Materials. Report by NEA Group of Experts OECD, Paris; 1979.

[17] Mostafa AMA, Mahmoud Uosif MA, Elsaman R, et al. Transmission of natural radiation from soil to maize plants and radiological hazards resulting from consumption in Upper Egypt. J Phys Sci. 2016; 27(3):25-49.

[18] Elham B, Masoud VM, Nasrin F. Natural radionuclide and radiological assessment of building materials in high background radiation areas of Ramsar, Iran. J Med Phys. 2013; 38(2):93-97.

[19] Awad A, El-Taher IA, Alruwaili HM. Assessment of natural radioactivity levels and radiation hazard indices for soil samples from Abha, Saudi Arabia. Results Phys. 2018;11:325-30.

[20] Muller G. Index of geo-accumulation in sediments of the Rhine River. GeoJournal 1969; 2:109-18.

[21] Hakanson L. An ecological risk index for aquatic pollution control: A sedimentological approach. Water Res. 1980;14:975-1001.

[22] Tomlinson DL, Wilson JG, Harris CR, et al. Problems in the Assessment of Heavy Metal Levels in Estuaries and the Formation of a Pollution Index. Helgol Wiss Meeresunters. 1980;33:566-75.

[23] ICRP. International Commission on Radiation Protection against Radon-222 at home and at work, Pergamon Press, Oxford; 1994.

[24] El-Taher A, Najam LA, Oraibi AH, et al. Effect of cement factory exhaust on radiological contents of surrounding soil samples in Assuit province-Egypt. J Phys Sci. 2017; 28(3):137-50.

[25] Santos JAS, Amaral RS, Nascimento JM. Radioactive disequilibrium and dynamic of natural radionuclides in soils in the state of pernambuco Brazil. Radia Prot Dosim. 2018: pp.1-11. doi:10.1093/rpd/ncy101.

[26] Johnson CK, Eigenberg RA, Doran JW, et al. Status of soil electrical conductivity studies by central states researchers. Trans Am Soc Agric Eng. 2005; 48(3):979-89.

[27] Bednar AJ, Jones WT, Boyd RE, et al. Geochemical parameters influencing tungsten mobility in soils. J Environ Qual. 2008; 37(1):229-33.

[28] USDA-United States Department of Agriculture, Soil Taxonomy, USDA-NRCS, Washington, DC, USA; 2012.

[29] Tsai TL, Liu C, Chuang CY, et al. The effects of physico-chemical properties on natural radioactivity levels, associated dose rate and evaluation of radiation hazard in the soil of Taiwan using statistical analysis. J Radioanal Nucl Chem. 2011; 288:927-36. doi 10.1007/s10967-011-1032-z.

[30] Rajalakshmi A, Chandrasekaran A, Ravisankar R. Soil pollution assessment in salt field area of Kelambakkam, Tamilnadu using different analytical techniques. Acta Ecologica Sinica 2017;37:373-78.

[31] Hans Wedepohl K. The composition of the continental crust. Geochim Cosmochim Acta 1995; 59(7):1217-32.

[32] Kabata-Pendias A, Pendias H. Trace Elements in Soils and Plants, CRC Press, New York, NY, USA; 2001.

[33] Turekian KK, Wedepohl KH. Distribution of the elements in some major units of the Earth's crust. Geol Soc Am Bull. 1961;72:17592. 